that a test for colour-blindness should be instituted in schools. The effect of eyestrain when using instruments, the sensitivity of the unaided eye in detecting small colour differences compared with the sensitivity when a colorimeter is employed, the mathematical developments of colorimetry in the United States, the merits of spectrophotometers, all came in for some comment. The excellent attendance, the interest of the members and the wealth of material as subjects for discussion, augur well for the future of the Group.

\section{ELECTRICALLY DRIVEN SHIPS}

$\mathrm{I}^{\mathrm{N}}$ war-time, while the question of capital cost is not the most important consideration, anything which increases the tonnage of the Navy and of the merchant fleet deserves serious attention. During the War of 1914-18, the attempts of the German Navy to blockade the British Isles by the unrestricted use of the submarine presented a similar problem. It was solved by the adoption of entirely novel methods. In addition to methods of speeding up ships of conventional design, the so-called 'fabricated" ship was constructed, and bridge builders and constructional engineers were called in to help. The parts of the hull were constructed, usually inland, and were sent to a convenient location on the coast where they were erected and launched.

In the Electrical Review of January 24, Mr. A. Regnauld makes a useful contribution to the solution of the problem by pointing out that ships' output can be increased by increasing their speed. This can be done by utilizing the large available electrical manufacturing industry for the production of the propelling machinery, and leaving the shipyards to deal with the production of the hulls.

In present circumstances, the manufacture of electric generating equipment is largely in abeyance and so also is the production of prime movers. If the shipyards could increase the output of hulls, the propelling equipment for the additional vessels could be constructed in its entirety by the electrical manufacturers and associated boiler manufacturers when steam turbines are installed. In all modern turbodriven steamships, some form of speed-reducing gearing must be employed. The most efficient propeller speed for merchant tonnage, namely, 12-15 knots, is 100-120 r.p.m. The economic speed of the steam turbine is very high, somewhere about 3,000 r.p.m., varying according to size. Neither the turbine nor the heavy-oil engine can be readily reversed. This involves the use of specially constructed turbines running in the reverse direction to the main turbines. These astern turbines are often of sufficient size to develop more than 50 per cent of the ahead power. They may only be required for half an hour or so, at the beginning and end of a voyage when manœuvring out of and into port. This represents a very uneconomical effect.

With the electric drive, particularly if two or more generators are employed to supply the maximum power, a very high degree of flexibility is obtained at all the different speeds used in service. If bridge control be fitted, it would prove of supreme value in any emergency which might arise. The maintenance charges comprised of overhauls and repairs are generally in favour of the electrically driven ship.

\section{FORTHCOMING EVENTS}

[Meeting marked with an asterisk is open to the public.]

\author{
Saturday, March 8
}

Society for Culturar. Relations with the U.S.S.R. (at the Royal Hotel, Woburn Place, London, W.C.1), at 1 p.m.-Prof. George Thomson: "Anthropological Theory in the U.S.S.R."

\section{Monday, March ro}

Royal Geographical Society (at Kensington Gore, London, S.W.7), at 5 p.m.-Mr. Gerald Seligman : "The Structure of a Temperate Glacier".

\section{Tuesday, March II}

Chemical Enginefring Group in conjunction with the Institution of Chemical Engineers (Joint Meeting) (in the Rooms of the Chemical Society, Burlington House, Piccadilly, London, W.1.), at 2.30 p.m.-Mr. E. W. Murray: "Ventilation (Natural and Artificial) in relation to the Blackout".

Illuminating Engineering Society (at the E.L.M.A. Lighting Service Bureau, 2 Savoy Hill, London, W.C.2), at 2.30 p.m.-Addresses on "Recent Work on A.R.P. Lighting Problems."

\section{Wednesday, March 12}

Geological Societry of London (at Burlington House, Piccadilly, London, W.1), at 2.30 p.m.-Annual Meeting. Prof. P. G. H. Boswell, F.R.S.: Presidential Address-Part 1: "The Status of Geology, a Review of Present Conditions"; Part 2: "The Stability of Minerals in Sedimentary Rocks".

\section{Friday, March 14}

Royal Astronomical Society (at Burlington House, Piccadilly, London, W.1.) at 3 p.m. Annual General Meeting. Professor H. C. Plummer, F.R.S.: "The History of the Vertical Telescope."

North-East CoAst Institution of EngINeERS and ShrpbUIlders (in the Mining Institute, Newcastleupon-Tyne), at 6 p.m.-Mr. J. Calderwood : "Some General Observations on Vibration".

\section{APPOINTMENTS VACANT}

APPLICATIONS are invited for the following appointments on or before the dates mentioned:

LECTURER FOR MECHANICAI ENGINEERING SUBJECTs--The Sectetary, Northampton Polytechnic, St. John Street, London, E.G.1 (March 17).

Demonstrator IN BIology--The Principal, Technical College, Kingston-upon-Thames.

Assistant Profkssor of MGTaLluRgy-The Director, Department of Mining and Metallurgical Engineering, Laval University, Quebec City, Canada.

\section{REPORTS AND OTHER PUBLICATIONS \\ (not included in the monthly Books Supplement)}

\section{Great Britain and Ireland}

Finance and the War. An Address given by Prof. F. Soddy to Members of the Parliamentary Labour Party at the House of Commons on Tuesday, November 9, 1940. Pp 16. (London: Economic
Reform Club and Institute.) $3 d$. Report on Conditions in Reception Areas. By a Committee under the Chairmanship of Mr. Geoffrey Shakespeare, M.P. Pp. 18. (London: H.M. Stationery Office.) 3d. net. [291 Tin Research Institute. Publication No. 102: Hot-Tinning; an Account of the Tinning of Steel, Iron, Copper, Brass and Bronze by the Hot-dipping Process. By Dr. C. E. Homer. Pp. 28. (Greenford : Tin Research Institute.)

\section{Other Countries}

Publications of the Alleghany Observatory of the University of Pittsburgh. Vol. 8, No. 5: Observations of Eros, 1930-1931. By Pittsburgh. Vol. 8, No. 5: (Pittsburgh, Pa. : University of PittsN. E. Wagman. Pp. 63-76. (Pittsburgh, Pa.: University of Pitts-
burgh Press.)

Government of Bengal : Department of Agriculture and Fisheries. Report on a Survey of the Fisheries of Bengal. Pp. iif +88 . (Alipore Bengal Government Press.) 